\title{
Influence of shooting period and extraction conditions on bioactive compounds in Turkish green tea
}

\author{
Ferhan BALCI ${ }^{1}$, Feramuz ÖZDEMIR ${ }^{1 *}$
}

\begin{abstract}
The aim of this study was to investigate the influence of different extraction temperatures $\left(75,85\right.$ and $\left.95{ }^{\circ} \mathrm{C}\right)$ and times $(3,5,10,15$ and $20 \mathrm{~min})$ on bioactive compounds in Turkish green tea produced and classified as Turkuaz, Kardelen and Antikyeşil by ÇAYKUR (the Turkish Tea Board) over three shooting periods. Green tea extracts were subjected to analyses of extraction yield, antioxidant capacity, total phenolic and flavonoid contents, and the phenolic and flavonoid composition. Total phenolic and flavonoid contents and the antioxidant capacity of samples increased when extraction temperatures and times were increased. Extraction yield, total phenolics, total flavonoids and the antioxidant capacity of the green teas were found in the range

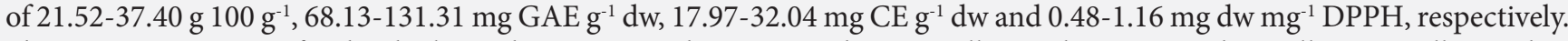
The average amounts of individual catechins, i.e. catechin, epicatechin, epigallocatechin, epicatechin gallate, epigallocatechin gallate, gallocatechin gallate, gallocatechin and catechin gallate were found in the range of 8.91-17.09, 4.29-9.55, 28.03-59.42, 8.02-14.61, 38.05-69.66, 2.53-18.53, 2.30-12.97 and 0.04-1.78 $\mathrm{mg} \mathrm{g}^{-1} \mathrm{dw}$, respectively.
\end{abstract}

Keywords: antioxidant capacity; catechin; extraction conditions; shooting periods; Turkish green tea.

Practical Application: This paper presents different extraction conditions in Turkish green tea of bioactive compounds such as phenolic and flavonoids. The results indicated that optimum green tea brewing for the consumers.

\section{Introduction}

Young shoots of tea bushes are processed into different products, such as black (fermented), green (unfermented) and oolong (semi - fermented) tea. Among these, green tea contains more catechins, which have received considerable interest for their potential benefits in human health for their antioxidant, anti-inflammatory, antimutagenic, anticarcinogenic and food preservative properties (Wang \& Helliwell, 2001; Cabrera et al., 2003, 2006; Higdon \& Frei, 2003; Perva-Uzunalić et al., 2006; Pharn-Huy et al., 2008; Yuan et al., 2011; Vuong et al., 2012). Green tea processing involves steaming, rolling, drying, sorting and packing. A critical step in this process is enzyme inactivation by steaming (Şahin-Nadeem et al., 2007).

The tea crop becomes ready for harvesting at nearly the same time in all plantations of the country. Tea is plucked three times between May and October, depending on weather conditions. In other words, there are three shooting periods in a season (Ozdemir et al., 1993).

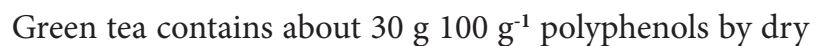
weight, which includes flavonols, flavonoids and phenolic acids. Catechins (about $10 \%$ of the dry weight basis) are the most prevalent flavonoids in green tea (Komes et al., 2010). They are divided into four primary compounds, i.e. epicatechin (EC), epicatechin gallate (ECG), epigallocatechin (EGC), epigallocatechin gallate (EGCG), with four secondary compounds i.e. catechin (C), catechin gallate (CG), gallocatechin (GC), and gallocatechin gallate (GCG). EGCG is the predominant catechin present in green tea leaves (Perva-Uzunalić et al., 2006).

There are many studies on green tea polyphenols especially associated with extraction conditions such as solvent type, extraction time, extraction temperature, agitation and loading percentage (Hertog et al.,1993; Khokhar \& Magnusdottir, 2002; Perva-Uzunalić et al., 2006; Xi et al., 2009; Komes et al., 2010). Also according to Wang \& Helliwell (2001), the extraction efficiency of polyphenols depends on the extraction time, temperature, $\mathrm{pH}$ and type of solvents.

In general consumer practice for the preparation of green tea, loose leaves of tea are brewed in just boiled water. A second way of preparing green tea is to brew a teabag in boiled water for 3-5 min. In the second procedure, the consumers may not get the full health benefits of green tea beverage because the infusion of the catechins is not optimal under household brewing conditions (Yuan et al., 2011; Vuong et al., 2012).

According to the literature survey, there has been no detailed comparison study related to the extraction conditions and their effects on the catechins. The present study was undertaken to identify the amount of bioactive components of extracted Turkish green tea. Different extraction temperatures $\left(75,85\right.$ and $\left.95^{\circ} \mathrm{C}\right)$ and times $(3,5,10,15$, and $20 \mathrm{~min})$ were selected to investigate their influences on the total phenolic content (TPC), total flavonoid 
content (TFC), antioxidant capacity (AC) and catechin content of green tea, which were classified as Turkuaz, Kardelen and Antikyeşil from three shooting periods.

\section{Materials and methods}

\subsection{Materials}

Green tea (Camellia sinensis L.) samples of the Kardelen, Antikyeşil and Turkuaz types were obtained from the Turkish tea board (ÇAYKUR) during three shooting periods of the 2010 tea season. Turkish green teas were separated into different categories according to size.

Fine particles which were sieved through a Middleton pakka were designated "Kardelen (Sample A)". The remaining tea in the Middleton pakka was separated through a winnower according to their specific gravity. The tea with a higher specific gravity was designated "Turkuaz (Sample C)" and those with a lower specific gravity were designated "Antikyeşil (Sample B)". The bulk density values of the A, B and C green tea samples were determined as $354 \mathrm{~kg} \mathrm{~m}^{-3}, 146 \mathrm{~kg} \mathrm{~m}^{-3}$ and $304 \mathrm{~kg} \mathrm{~m}^{-3}$, respectively (Şahin-Nadeem et al., 2013). The catechin standards and other chemicals were purchased from Sigma-Aldrich.

\subsection{Preparation of green tea extracts}

Extraction was accomplished according to the procedure of Gürses \& Artık (1987). $2.83 \mathrm{~g}$ of the green tea samples were immediately added to $250 \mathrm{~mL}$ of water conditioned at the extraction temperature in a round-bottom flask. The mixture was extracted by steady shaking with an orbital shaking water bath (GFL, Germany) at $150 \mathrm{rpm}$ to submerge every particle in the water and to perform forced convective diffusion. The mixtures were uniformly maintained at three different temperatures $\left(75,85\right.$ and $\left.95^{\circ} \mathrm{C}\right)$, which were checked using a thermocouple throughout each extraction process. The extraction was performed in a time-dependent manner $(3,5,10,15$ and $20 \mathrm{~min})$. The extracts were filtered (Whatman No. 42 ), cooled and stored at $-18{ }^{\circ} \mathrm{C}$ until analysis.

\subsection{Determination of extract yield}

$15 \mathrm{~mL}$ of the filtered extracts were dried in an oven (Memmert, Germany) at $65^{\circ} \mathrm{C}$ until a constant weight. Extraction yield was calculated using Equation 1:

$E Y(g / 100 g)=\left(W_{1} x 15\right) / W_{2}$

where $E Y$ is the extraction yield, $W_{1}$ is the weight of the dried extract and $W_{2}$ is the dry matter of tea (Gürses \& Artık, 1987).

\subsection{Determination of total phenolic content}

The total phenolic content analyses were performed according to Torun et al. (2014). For this purpose, $0.5 \mathrm{~mL}$ of the extract was treated with $2.5 \mathrm{~mL}$ of $0.1 \mathrm{~N}$ Folin-Ciocalteu reagent and $2 \mathrm{~mL}$ of $\mathrm{Na}_{2} \mathrm{CO}_{3}(75 \mathrm{~g} / \mathrm{L})$. This mixture was incubated at $50{ }^{\circ} \mathrm{C}$ for $5 \mathrm{~min}$ and cooled immediately. The absorbance of the final solution was recorded with a spectrophotometer (Shimadzu
UV - Vis 160A, Japan) at $760 \mathrm{~nm}$. The results were expressed as gallic acid equivalents (GAE) (g gallic acid/L).

\subsection{Determination of total flavonoid content}

$2.5 \mathrm{~mL}$ of distilled water and $150 \mu \mathrm{L}$ of a $5 \% \mathrm{NaNO}_{2}$ solution were added into $0.5 \mathrm{~mL}$ of the extract sample, then allowed to stand for $5 \mathrm{~min}$ after vortexing. After that, $300 \mu \mathrm{L}$ of a $10 \% \mathrm{AlCl}_{3}$ solution was added to the solution and allowed to stand for $5 \mathrm{~min}$ again. A further $1 \mathrm{~mL}$ of $1 \mathrm{M} \mathrm{NaOH}$ was added and the final volume was made up to $5 \mathrm{~mL}$ with distilled water. Sample absorbance was measured at $510 \mathrm{~nm}$ by using a spectrophotometer (Shimadzu UV-Vis 160A, Japan). The results were expressed as $(+)$ - catechin equivalents $(\mathrm{CE})\left(\mathrm{g}(+)\right.$ - catechin $\left.\mathrm{L}^{-1}\right)$ (Chang et al., 2006).

\subsection{Determination of antioxidant capacity using DPPH}

DPPH (2,2 Diphenyl - 1 - picryhydrazyl radical) radical scavenging was assessed according to the literature procedure (Gadow et al., 1997; Maisuthisakul et al., 2007). $100 \mu \mathrm{L}$ of the diluted extract (prepared at four different concentrations to provide 10 to $90 \%$ inhibition) were added into $4 \mathrm{~mL}$ of freshly prepared DPPH solutions (6 $\times 10^{-5} \mathrm{M}$ in $\left.\mathrm{MeOH}\right)$. The mixtures were then shaken and placed in the dark at room temperature for $30 \mathrm{~min}$. Absorbance values of the final solutions $\left(\mathrm{A}_{\mathrm{s}}\right)$ were recorded at $516 \mathrm{~nm}$ using a spectrophotometer (Shimadzu UV-Vis 160A) with respect to the control (distilled water instead of extract in the DPPH solution) solution $\left(\mathrm{A}_{c}\right)$. The inhibition percentage of the DPPH radical was calculated by using Equation 2:

Inhibition $(\%)=\left[\left(A_{c}-A_{s}\right) / A_{c}\right] \times 100$

The extract concentration providing $50 \%$ inhibition $\left(I C_{50}\right)$ was calculated by plotting the concentration versus inhibition percentage.

\subsection{Determination of catechin contents by HPLC}

The tea catechin content of the extracts was determined according to the method of Zuo et al. (2002). All green tea extracts were filtered through a membrane filter $(0.45 \mu \mathrm{m}$ Macherey Nagel, Germany), and $20 \mu \mathrm{L}$ of each sample were injected for HPLC analysis.

The chromatographic separation was performed using a solvent delivery system (20AD, Shimadzu, Japan) coupled with an auto - sampler (SIL-20A Prominence, Shimadzu, Japan), column (LiChroCART ${ }^{\circledR} 250-4250$ x 4 mm $5 \mu$ m Nucleosil $^{\circledR}$ 100-5 C 18). Individual peaks were detected by an SPD-M20A Diode Array Detector (Shimadzu, Japan) which was controlled by LC solution software. The mobile phase was HPLC grade methanol (solvent $\mathrm{A}$ ) and consisted of $0.2 \%$ trifluoroacetic acid (solvent B) at a flow rate of $1 \mathrm{~mL} \mathrm{~min}{ }^{-1}$. Elution was performed with a gradient started at $5 \%$ A for $1 \mathrm{~min}$, followed by a linear increase of solvent $A$ to $63 \%$ in $28 \mathrm{~min}$, after which the mobile phase composition was brought back to the initial conditions in $5 \mathrm{~min}$ for the next run. Chromatograms were recorded at $280 \mathrm{~nm}$. Catechin compounds were identified by comparing the retention times and spectral data with authentic standards. 
Calibration curves were obtained at detection for all catechins using a series of standard solutions over a concentration range from 1 to $100 \mathrm{mg} \mathrm{L}^{-1}$. All calibration curves were linear over the concentration ranges tested with correlation coefficients $\geq 0.998$.

\subsection{Statistical analysis}

The experiment was set up as a factorial design for the extraction temperature and time $(3 \times 5)$, using duplicate samples. The data were then subjected to analysis of variance, and appropriate means separation was conducted using Duncan's multiple - range test using the SAS System for Windows V7 software (SAS Institute Inc., Cary, NC, USA).

\section{Results and discussion}

\subsection{Extraction yield}

All of the experimental factors (tea class, extraction temperature and time) had a significant $(\mathrm{P}<0.01)$ effect on the extraction yield of the samples, with a range of 21.52-37.40 ${\mathrm{g} 100 \mathrm{~g} \mathrm{~g}^{-1}}^{-1}$ (Table 1). The Sample A showed the highest extraction yield at $95^{\circ} \mathrm{C}$ for the 20 min extraction procedure (Table 1 ), which may be related to the particle size of the samples. Indeed, the Sample A had smaller particles than the others, hence the extraction equilibrium time decreased. However, the extraction yield of the samples increased with increasing the temperature and time. Extraction yield plays an important role in the quality of green tea by impacting the colour, taste and flavour. In this study, the equilibration time of the extraction yield was found to be around $5 \mathrm{~min}$. From this point of view, especially in samples of the third shooting period, green tea should be extracted for over 5 min before consumption.

Yao et al. (2004) reported the water extraction yield of commercial green teas as $32.84 \%$. According to Perva-Uzunalić et al. (2006) the extraction yield depends on the extraction temperature of the green tea sample, and is usually in the range of $29.2-43 \%$.
In addition, Ozdemir et al. (1993) reported that the extraction yield of Turkish black teas of the first shooting period is higher than samples of the second and third shooting periods. Our findings are in agreement with the above studies. Small differences may be observed due to differences in tea origin, the number of coarse leaves, the extraction procedure, particle size and growing conditions of the tea.

\subsection{Total phenolic and flavonoid content}

The total phenolic and flavonoid contents of the samples, which contained nearly $25 \% \mathrm{TPC}$, were found in the range of 68.13-131.31 $\mathrm{mg} \mathrm{GAE} \mathrm{g}^{-1} \mathrm{dw}$ and 17.97-32.04 $\mathrm{mg} \mathrm{CE} \mathrm{g}^{-1} \mathrm{dw}$ as shown in Table 2 and 3, respectively. The highest TPC and TFC values were observed in Sample A extracted at $95^{\circ} \mathrm{C}$ for $20 \mathrm{~min}$. Previous studies reported the total phenolic content of green tea as 11.42-27.10 g GAE $100 \mathrm{~g}^{-1}$, which corresponds to 114.2-271.0 mg GAE g ${ }^{-1}$ (Astill et al., 2001; Turkmen et al., 2006; Karori et al., 2007; Anesini et al., 2008). These results are slightly lower as compared to previously reported results for green tea, but this may be related to the extraction conditions, tea clone, geographic origin, growing conditions, processing conditions, differences in plucking season and plucking standardisation.

In Turkey, the first shooting period starts in May, and tea is plucked three times until October, depending on the weather conditions. During the nearly seven months of winter, tea undergoes a seasonal dormancy period. Consequently, Turkish tea bushes of the first shooting period contain a higher amount of total phenolic and flavonid content in the apical bud and leaves than the following shooting periods. The total phenolic and flavonoid contents of these parts are higher than the other leaves and stalks of the tea plant. As a matter of fact, the total phenolic and flavonoid contents of samples obtained from the first shooting period were higher than those from the second and the third shooting period. Moreover, in the second and the third shooting periods, both leaves and buds are harvested. Therefore,

Table 1. Duncan's multiple - range test results of extraction yield values (g/100 g).

\begin{tabular}{|c|c|c|c|c|c|c|}
\hline \multirow{5}{*}{ 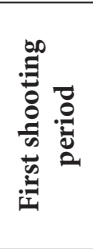 } & \multirow{2}{*}{ Class $(\mathrm{n}=30)$} & Sample A & Sample B & Sample C & & \\
\hline & & $37.4^{a} \pm 0.4$ & $31.7^{\mathrm{b}} \pm 0.6$ & $29.3^{c} \pm 0.7$ & & \\
\hline & \multirow{2}{*}{ Temperature $(\mathbf{n}=\mathbf{3 0})$} & $75^{\circ} \mathrm{C}$ & $85^{\circ} \mathrm{C}$ & $95^{\circ} \mathrm{C}$ & & \\
\hline & & $31.2^{c} \pm 0.8$ & $32.5^{\mathrm{b}} \pm 0.7$ & $34.7^{\mathrm{a}} \pm 0.9$ & & \\
\hline & Time $(n=18)$ & $28.7^{\mathrm{e}} \pm 1.2$ & $31.7^{\mathrm{d}} \pm 1.0$ & $33.3^{c} \pm 0.9$ & $34.5^{\mathrm{b}} \pm 0.8$ & $35.72^{\mathrm{a}} \pm 0.82$ \\
\hline \multirow{4}{*}{ 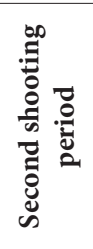 } & Class $(\mathrm{n}=30)$ & Sample A & Sample B & Sample C & & \\
\hline & Temperature $(\mathbf{n}=\mathbf{3 0})$ & $26.9^{c} \pm 1.2$ & $29.8^{\mathrm{b}} \pm 1.1$ & $32.1^{\mathrm{a}} \pm 1.0$ & & \\
\hline & \multirow{2}{*}{ Time $(n=18)$} & $3 \mathrm{~min}$ & $5 \mathrm{~min}$ & $10 \mathrm{~min}$ & $15 \mathrm{~min}$ & $20 \mathrm{~min}$ \\
\hline & & $22.5^{\mathrm{d}} \pm 1.3$ & $28.1^{\mathrm{c}} \pm 1.4$ & $31.5^{\mathrm{b}} \pm 1.1$ & $31.5^{\mathrm{b}} \pm 1.0$ & $34.39^{\mathrm{a}} \pm 1.09$ \\
\hline \multirow{2}{*}{ 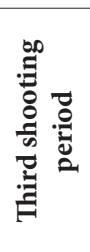 } & \multirow{2}{*}{ Class $(\mathrm{n}=30)$} & Sample C & Sample B & Sample A & & \\
\hline & & $24.4^{\mathrm{b}} \pm 1.1$ & $25.4^{\mathrm{b}} \pm 0.7$ & $30.4^{\mathrm{a}} \pm 0.7$ & & \\
\hline
\end{tabular}

Results are means \pm standard error. The values within a column with different superscript letters are significantly $(\mathrm{P}<0.01)$ different. 
Table 2. Duncan's multiple - range test results of total phenolic content (mg GAE/g dw).

\begin{tabular}{|c|c|c|c|c|c|c|}
\hline \multirow{6}{*}{ 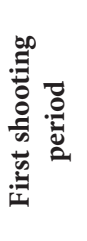 } & \multirow{2}{*}{ Class $(\mathbf{n}=30)$} & Sample A & Sample B & Sample C & & \\
\hline & & $130.8^{\mathrm{a}} \pm 4.0$ & $113.0^{\mathrm{b}} \pm 3.2$ & $101.7^{c} \pm 4.5$ & & \\
\hline & \multirow{2}{*}{ Temperature $(\mathbf{n}=\mathbf{3 0})$} & $75^{\circ} \mathrm{C}$ & $85^{\circ} \mathrm{C}$ & $95^{\circ} \mathrm{C}$ & & \\
\hline & & $103.15^{c} \pm 3.1$ & $113.4^{\mathrm{b}} \pm 4.3$ & $128.9^{\mathrm{a}} \pm 4.7$ & & \\
\hline & \multirow{2}{*}{ Time $(n=18)$} & $3 \mathrm{~min}$ & $5 \mathrm{~min}$ & $10 \mathrm{~min}$ & $15 \mathrm{~min}$ & $20 \mathrm{~min}$ \\
\hline & & $90.6^{\mathrm{d}} \pm 5.5$ & $109.2^{c} \pm 5.2$ & $118.6^{\mathrm{b}} \pm 4.6$ & $126.1^{\mathrm{a}} \pm 4.2$ & $131.3^{\mathrm{a}} \pm 4.3$ \\
\hline \multirow{6}{*}{ 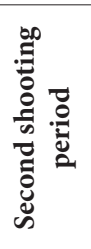 } & \multirow{2}{*}{ Class $(\mathrm{n}=30)$} & Sample A & Sample B & Sample C & & \\
\hline & & $134.8^{\mathrm{a}} \pm 4.3$ & $100.2^{\mathrm{b}} \pm 4.3$ & $97.3^{\mathrm{b}} \pm 5.6$ & & \\
\hline & \multirow{2}{*}{ Temperature $(\mathbf{n}=30)$} & $75^{\circ} \mathrm{C}$ & $85^{\circ} \mathrm{C}$ & $95^{\circ} \mathrm{C}$ & & \\
\hline & & $101.2^{c} \pm 5.8$ & $110.1^{\mathrm{b}} \pm 5.7$ & $121.0^{\mathrm{a}} \pm 5.1$ & & \\
\hline & \multirow{2}{*}{ Time $(n=18)$} & $3 \mathrm{~min}$ & $5 \mathrm{~min}$ & $10 \mathrm{~min}$ & $15 \mathrm{~min}$ & $20 \mathrm{~min}$ \\
\hline & & $72.2^{\mathrm{d}} \pm 5.8$ & $103.2^{c} \pm 6.3$ & $119.8^{\mathrm{b}} \pm 5.9$ & $123.7^{\mathrm{b}} \pm 4.1$ & $134.9^{\mathrm{a}} \pm 3.9$ \\
\hline \multirow{6}{*}{ 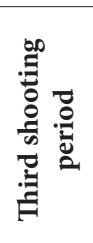 } & \multirow{2}{*}{ Class $(\mathrm{n}=30)$} & Sample A & Sample B & Sample C & & \\
\hline & & $109.9^{\mathrm{a}} \pm 4.5$ & $89.3^{b} \pm 3.2$ & $92.8^{\mathrm{b}} \pm 4.7$ & & \\
\hline & \multirow{2}{*}{ Temperature $(\mathbf{n}=30)$} & $75^{\circ} \mathrm{C}$ & $85^{\circ} \mathrm{C}$ & $95^{\circ} \mathrm{C}$ & & \\
\hline & & $90.2^{\mathrm{b}} \pm 4.0$ & $98.1^{\mathrm{a} \cdot \mathrm{b}} \pm 4.5$ & $103.7^{\mathrm{a}} \pm 4.7$ & & \\
\hline & \multirow{2}{*}{ Time $(n=18)$} & $3 \mathrm{~min}$ & $5 \mathrm{~min}$ & $10 \mathrm{~min}$ & $15 \mathrm{~min}$ & $20 \mathrm{~min}$ \\
\hline & & $68.1^{\mathrm{d}} \pm 3.5$ & $90.1^{c} \pm 5.1$ & $100.4^{b \cdot c} \pm 3.6$ & $106.3^{\mathrm{b}} \pm 4.2$ & $121.8^{\mathrm{a}} \pm 3.6$ \\
\hline
\end{tabular}

Results are means \pm standard error. The values within a column with different superscript letters are significantly $(\mathrm{P}<0.01)$ different.

Table 3. Duncan's multiple - range test results of total flavonoid content (mg CE/g dw).

\begin{tabular}{|c|c|c|c|c|c|c|}
\hline \multirow{6}{*}{ 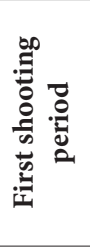 } & \multirow{2}{*}{ Class $(n=30)$} & Sample A & Sample B & Sample C & & \\
\hline & & $31.8^{\mathrm{a}} \pm 0.5$ & $28.3^{\mathrm{b}} \pm 0.7$ & $25.0^{c} \pm 0.9$ & & \\
\hline & \multirow{2}{*}{ Temperature $(\mathbf{n}=30)$} & $75^{\circ} \mathrm{C}$ & $85^{\circ} \mathrm{C}$ & $95^{\circ} \mathrm{C}$ & & \\
\hline & & $26.0^{b} \pm 0.7$ & $29.6^{a} \pm 0.8$ & $29.4^{\mathrm{a}} \pm 1.0$ & & \\
\hline & \multirow{2}{*}{ Time $(n=18)$} & $3 \mathrm{~min}$ & $5 \mathrm{~min}$ & $10 \mathrm{~min}$ & $15 \mathrm{~min}$ & $20 \mathrm{~min}$ \\
\hline & & $23.7^{\mathrm{e}} \pm 1.2$ & $27.1^{\mathrm{d}} \pm 1.1$ & $28.8^{c} \pm 0.8$ & $30.2^{b} \pm 0.7$ & $32.0^{\mathrm{a}} \pm 0.7$ \\
\hline \multirow{6}{*}{ 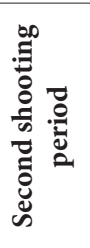 } & \multirow{2}{*}{ Class $(\mathrm{n}=30)$} & Sample A & Sample B & Sample C & & \\
\hline & & $31.8^{\mathrm{a}} \pm 0.8$ & $25.6^{\mathrm{b}} \pm 1.9$ & $22.7^{\mathrm{c}} \pm 1.1$ & & \\
\hline & \multirow{2}{*}{ Temperature $(\mathbf{n}=\mathbf{3 0})$} & $75^{\circ} \mathrm{C}$ & $85^{\circ} \mathrm{C}$ & $95^{\circ} \mathrm{C}$ & & \\
\hline & & $23.7^{\mathrm{b}} \pm 1.2$ & $27.8^{\mathrm{a}} \pm 1.2$ & $28.6^{\mathrm{a}} \pm 1.0$ & & \\
\hline & \multirow{2}{*}{ Time $(n=18)$} & $3 \mathrm{~min}$ & $5 \mathrm{~min}$ & $10 \mathrm{~min}$ & $15 \mathrm{~min}$ & $20 \mathrm{~min}$ \\
\hline & & $19.9^{\mathrm{d}} \pm 1.5$ & $25.4^{c} \pm 1.4$ & $28.2^{\mathrm{b}} \pm 1.2$ & $29.2^{\mathrm{b}} \pm 1.0$ & $31.6^{\mathrm{a}} \pm 1.0$ \\
\hline \multirow{6}{*}{ 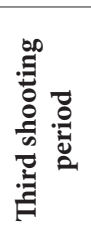 } & \multirow{2}{*}{ Class $(\mathrm{n}=\mathbf{3 0})$} & Sample A & Sample B & Sample C & & \\
\hline & & $27.1^{\mathrm{a}} \pm 0.8$ & $21.1^{\mathrm{b}} \pm 0.8$ & $21.9^{\mathrm{b}} \pm 0.9$ & & \\
\hline & \multirow{2}{*}{ Temperature $(\mathbf{n}=\mathbf{3 0})$} & $75^{\circ} \mathrm{C}$ & $85^{\circ} \mathrm{C}$ & $95^{\circ} \mathrm{C}$ & & \\
\hline & & $21.1^{\mathrm{c}} \pm 0.9$ & $23.3^{\mathrm{b}} \pm 0.8$ & $25.7^{\mathrm{a}} \pm 0.9$ & & \\
\hline & \multirow{2}{*}{ Time $(\mathrm{n}=18)$} & $3 \mathrm{~min}$ & $5 \mathrm{~min}$ & $10 \mathrm{~min}$ & $15 \mathrm{~min}$ & $20 \mathrm{~min}$ \\
\hline & & $18.0^{\mathrm{e}} \pm 1.1$ & $21.3^{\mathrm{d}} \pm 1.1$ & $23.6^{c} \pm 0.8$ & $25.8^{\mathrm{b}} \pm 0.9$ & $28.2^{\mathrm{a}} \pm 0.7$ \\
\hline
\end{tabular}

Results are means \pm standard error. The values within a column with different superscript letters are significantly $(\mathrm{P}<0.01)$ different.

a decrease was observed in the total phenolic and flavonoid content at each shooting periods in this study. There are also examples available in the literature about black tea, green tea and buds, which are in agreement with our results (Ozdemir et al., 1993; Singh et al., 1999). However Şahin-Nadeem et al. (2007) reported that green tea obtained from the first and second shooting periods had higher phenolic contents than obtained from subsequent shooting periods.

The effect of temperature was also studied, which showed a positive effect on the extraction efficiencies of the total phenolic and flavonoid contents. In a previous study, an increase in extraction temperature increased the phenolic and flavonoid contents of green and black tea (Astill et al., 2001; Khokhar \& Magnusdottir, 2002; Ziaedini et al., 2010). Also, the results showed that nearly $50 \%$ of the total phenolic and flavonoids of the samples are extracted in the first three minutes.

\subsection{Antioxidant capacity}

Antioxidant capacity is related to the phenolic compounds of green tea. It reflects the amount of active components $\left(I C_{50}\right)$ scavenging $50 \%$ of the DPPH radical. The $I C_{50}$ values of the green tea samples were found in the range of $0.48-1.16 \mathrm{mg} \mathrm{dw} \mathrm{mg}^{-1} \mathrm{DPPH}$, as shown in Table 4 . The lowest $I C_{50}$ value, thereby the highest antioxidant capacity, was determined in the Sample A extracted at $95^{\circ} \mathrm{C}$ for $20 \mathrm{~min}$, from the first shooting period. The antioxidant capacity of the samples was significantly $(\mathrm{P}<0.01)$ affected by the extraction temperature and time. Similar results were found 
in some previous studies (Samaniego-Sanchez et al., 2011; Komes et al., 2010).

\subsection{Catechin content}

Catechins are responsible for the health effects, bitterness and astringency of green tea. The catechin content in Sample A of the first shooting period (showing the highest total phenolic and flavonoid contents in this study) were identified by HPLC and the evaluated results are given in Table 5. The catechins are composed of catechin (C), epicatechin (EC), epigallocatechin (EGC), epicatechin gallate (ECG), epigallocatechin gallate (EGCG), gallocatechin gallate (GCG), gallocatechin (GC) and catechin gallate (CG).

The amounts of individual catechins, i.e. C, EC, EGC, ECG, EGCG, GCG, GC and CG, were found in the range of
8.91- 17.09, 4.29-9.55, 28.03-59.42 $\mathrm{mg} \mathrm{g}^{-1} \mathrm{dw}, 8.02-14.61 \mathrm{mg} \mathrm{g}^{-1} \mathrm{dw}$, $38.05-69.66 \mathrm{mg} \mathrm{g}^{-1} \mathrm{dw}, 2.53-18.53 \mathrm{mg} \mathrm{g}^{-1} \mathrm{dw}, 2.30-12.97 \mathrm{mg} \mathrm{g}^{-1} \mathrm{dw}$ and $0.04-1.78 \mathrm{mg} \mathrm{g}^{-1} \mathrm{dw}$, respectively (Table 5). EGCG was the major constituent of the Sample A green tea, as shown in Table 5. It is well-known that EGCG composes nearly $60 \%$ of the total catechins in tea (Khokhar \& Magnusdottir, 2002; Zaveri, 2006). The EGCG content was not affected significantly $(\mathrm{P}<0.01)$ by an extraction time beyond three minutes.

The results show that the C, EC, EGC, ECG, EGCG and GC contents decreased when the extraction temperature was increased from $75^{\circ} \mathrm{C}$ to $85^{\circ} \mathrm{C}$. Ziaedini et al. (2010) reported that $\mathrm{EGC}$ and $\mathrm{EC}$ decrease when the temperature is increased from $80{ }^{\circ} \mathrm{C}$ to $90^{\circ} \mathrm{C}$, which they associated with degradation, oxidation or epimerization of these compounds. Similar results were also reported by Perva-Uzunalić et al. (2006).

Table 4. Duncan's multiple - range test results of $\mathrm{IC}_{50}$ values ( $\left.\mathrm{mg} \mathrm{dw} / \mathrm{mg} \mathrm{DPPH}\right)$.

\begin{tabular}{|c|c|c|c|c|c|c|}
\hline \multirow{6}{*}{ 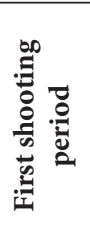 } & \multirow{2}{*}{ Class $(\mathbf{n}=30)$} & Sample A & Sample B & Sample C & & \\
\hline & & $0.8^{\mathrm{a}} \pm 0.0$ & $0.6^{\mathrm{b}} \pm 0.0$ & $0.5^{\mathrm{c}} \pm 0.0$ & & \\
\hline & \multirow{2}{*}{ Temperature $(\mathbf{n}=\mathbf{3 0})$} & $75^{\circ} \mathrm{C}$ & $85^{\circ} \mathrm{C}$ & $95^{\circ} \mathrm{C}$ & & \\
\hline & & $0.7^{\mathrm{a}} \pm 0.0$ & $0.7^{\mathrm{a}} \pm 0.0$ & $0.5^{\mathrm{b}} \pm 0.0$ & & \\
\hline & \multirow{2}{*}{ Time $(\mathbf{n}=18)$} & $3 \mathrm{~min}$ & $5 \mathrm{~min}$ & $10 \mathrm{~min}$ & $15 \mathrm{~min}$ & $20 \mathrm{~min}$ \\
\hline & & $0.8^{\mathrm{a}} \pm 0.0$ & $0.7^{\mathrm{b}} \pm 0.0$ & $0.6^{c} \pm 0.0$ & $0.6^{\mathrm{c}} \pm 0.0$ & $0.5^{\mathrm{d}} \pm 0.0$ \\
\hline \multirow{6}{*}{ 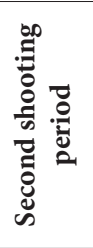 } & \multirow{2}{*}{ Class $(\mathbf{n}=30)$} & Sample A & Sample B & Sample C & & \\
\hline & & $0.9^{\mathrm{a}} \pm 0.1$ & $0.8^{\mathrm{b}} \pm 0.0$ & $0.6^{c} \pm 0.0$ & & \\
\hline & \multirow{2}{*}{ Temperature $(\mathbf{n}=\mathbf{3 0})$} & $75^{\circ} \mathrm{C}$ & $85^{\circ} \mathrm{C}$ & $95^{\circ} \mathrm{C}$ & & \\
\hline & & $0.8^{\mathrm{a}} \pm 0.0$ & $0.8^{\mathrm{b}} \pm 0.0$ & $0.7^{\mathrm{b}} \pm 0.0$ & & \\
\hline & \multirow{2}{*}{ Time $(n=18)$} & $3 \mathrm{~min}$ & $5 \mathrm{~min}$ & $10 \mathrm{~min}$ & $15 \mathrm{~min}$ & $20 \mathrm{~min}$ \\
\hline & & $1.1 \mathrm{a} \pm 0.1$ & $0.8^{\mathrm{b}} \pm 0.0$ & $0.7^{c} \pm 0.0$ & $0.7^{\mathcal{c}} \pm 0.0$ & $0.5^{\mathrm{d}} \pm 0.0$ \\
\hline \multirow{6}{*}{ 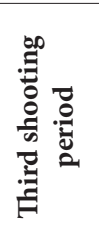 } & \multirow{2}{*}{ Class $(n=30)$} & Sample A & Sample B & Sample C & & \\
\hline & & $1.0^{\mathrm{a}} \pm 0.0$ & $0.8^{\mathrm{b}} \pm 0.0$ & $0.7^{c} \pm 0.0$ & & \\
\hline & \multirow{2}{*}{ Temperature $(\mathbf{n}=30)$} & $75^{\circ} \mathrm{C}$ & $85^{\circ} \mathrm{C}$ & $95^{\circ} \mathrm{C}$ & & \\
\hline & & $0.9^{\mathrm{a}} \pm 0.0$ & $0.8^{\mathrm{b}} \pm 0.0$ & $0.8^{\mathrm{b}} \pm 0.0$ & & \\
\hline & \multirow{2}{*}{ Time $(n=18)$} & $3 \mathrm{~min}$ & $5 \mathrm{~min}$ & $10 \mathrm{~min}$ & $15 \mathrm{~min}$ & $20 \mathrm{~min}$ \\
\hline & & $1.1^{\mathrm{a}} \pm 0.1$ & $0.9^{\mathrm{b}} \pm 0.0$ & $0.7^{\mathrm{c}} \pm 0.0$ & $0.7^{\mathrm{c}} \pm 0.0$ & $0.6^{\mathrm{d}} \pm 0.0$ \\
\hline
\end{tabular}

Results are means \pm standard error. The values within a column with different superscript letters are significantly $(\mathrm{P}<0.01)$ different.

Table 5. Individual catechins content of Sample A of the first shooting period as a function of extraction temperature and time (mg/g dw).

\begin{tabular}{|c|c|c|c|c|c|c|c|c|c|}
\hline & Temperature & Time (min) & GC & EGC & C & EGCG & EC & GCG & ECG \\
\hline & & 3 & $3.8^{\mathrm{a}} \pm 0.0$ & $41.9^{\mathrm{a}} \pm 0.0$ & $12.5^{\mathrm{a}} \pm 0.0$ & $56.5^{\mathrm{a}} \pm 0.1$ & $8.9^{\mathrm{a}} \pm 0.0$ & $2.5^{\mathrm{a}} \pm 0.0$ & $10.9^{\mathrm{a}} \pm 0.0$ \\
\hline & & 5 & $4.2^{\mathrm{b}} \pm 0.0$ & $42.1^{\mathrm{a}} \pm 0.9$ & $12.9^{\mathrm{a}, \mathrm{b}} \pm 0.0$ & $59.4^{\mathrm{b}} \pm 0.1$ & $9.0^{\mathrm{a}, \mathrm{b}} \pm 0.0$ & $3.0^{\mathrm{b}} \pm 0.0$ & $11.7^{\mathrm{a}, \mathrm{b}} \pm 0.0$ \\
\hline & $75^{\circ} \mathrm{C}$ & 10 & $4.7^{c} \pm 0.0$ & $42.6^{\mathrm{a}} \pm 0.0$ & $13.9^{\mathrm{b}} \pm 0.0$ & $59.8^{\mathrm{b}} \pm 0.0$ & $9.3^{\mathrm{b}, \mathrm{c}} \pm 0.0$ & $3.6^{c} \pm 0.0$ & $11.9^{\mathrm{a}, \mathrm{b}} \pm 0.1$ \\
\hline & & 15 & $5.3^{c} \pm 0.0$ & $43.2^{\mathrm{b}} \pm 0.1$ & $14.6^{c} \pm 0.0$ & $60.1^{b} \pm 0.3$ & $9.5^{c} \pm 0.0$ & $4.2^{\mathrm{d}} \pm 0.0$ & $12.6^{\mathrm{a}, \mathrm{b}} \pm 0.0$ \\
\hline & & 20 & $5.9^{\mathrm{d}} \pm 0.0$ & $44.1^{\mathrm{a}, \mathrm{b}} \pm 0.2$ & $14.8^{c} \pm 0.0$ & $61.7^{\mathrm{b}} \pm 0.1$ & $9.5^{c} \pm 0.0$ & $4.6^{\mathrm{e}} \pm 0.0$ & $13.0^{\mathrm{b}} \pm 0.0$ \\
\hline & & 3 & $2.3^{\mathrm{a}} \pm 0.0$ & $28.0^{\mathrm{a}} \pm 0.3$ & $8.9^{a} \pm 0.0$ & $38.0^{\mathrm{a}} \pm 0.3$ & $4.3^{a} \pm 0.1$ & $2.4^{\mathrm{a}} \pm 0.0$ & $8.0^{\mathrm{a}} \pm 0.1$ \\
\hline & & 5 & $2.6^{\mathrm{a}} \pm 0.0$ & $28.7^{\mathrm{a}} \pm 0.0$ & $9.8^{\mathrm{a}, \mathrm{b}} \pm 0.0$ & $41.2^{\mathrm{a}, \mathrm{b}} \pm 0.2$ & $4.8^{\mathrm{a}, \mathrm{b}} \pm 0.1$ & $2.8^{\mathrm{a}} \pm 0.0$ & $8.6^{a} \pm 0.0$ \\
\hline \multirow[t]{8}{*}{ Sample A } & $85^{\circ} \mathrm{C}$ & 10 & $3.6^{\mathrm{b}} \pm 0.0$ & $28.9^{\mathrm{a}} \pm 0.1$ & $10.0^{\mathrm{a}, \mathrm{b}} \pm 0.0$ & $41.8^{\mathrm{a}, \mathrm{b}} \pm 0.2$ & $5.9^{\mathrm{a}, \mathrm{b}, \mathrm{c}} \pm 0.0$ & $4.1^{\mathrm{b}} \pm 0.0$ & $9.3^{a} \pm 0.0$ \\
\hline & & 15 & $5.1^{\mathrm{b}} \pm 0.0$ & $29.0^{\mathrm{a}} \pm 0.1$ & $10.7^{\mathrm{b}} \pm 0.0$ & $41.9^{\mathrm{a}, \mathrm{b}} \pm 0.0$ & $6.7^{\mathrm{b}, \mathrm{c}} \pm 0.0$ & $5.2^{c} \pm 0.0$ & $9.3^{\mathrm{a}} \pm 0.0$ \\
\hline & & 20 & $5.4^{c} \pm 0.0$ & $30.3^{\mathrm{a}} \pm 0.1$ & $10.9^{\mathrm{b}} \pm 0.0$ & $43.3^{\mathrm{b}} \pm 0.2$ & $6.8^{c} \pm 0.0$ & $5.4^{c} \pm 0.0$ & $9.4^{\mathrm{a}} \pm 0.0$ \\
\hline & & 3 & $3.8^{\mathrm{a}} \pm 0.0$ & $49.6^{\mathrm{a}} \pm 0.9$ & $12.7^{\mathrm{a}} \pm 0.3$ & $51.4^{\mathrm{a}} \pm 1.2$ & $6.8^{\mathrm{a}} \pm 0.1$ & $4.0^{\mathrm{a}} \pm 0.1$ & $9.5^{\mathrm{a}} \pm 0.2$ \\
\hline & & 5 & $4.7^{\mathrm{b}} \pm 0.0$ & $49.9^{\mathrm{a}} \pm 0.0$ & $13.4^{\mathrm{a}} \pm 0.2$ & $66.2^{\mathrm{b}} \pm 0.1$ & $7.4^{\mathrm{a}, \mathrm{b}} \pm 0.1$ & $6.7^{b} \pm 0.0$ & $13.4^{\mathrm{b}} \pm 0.0$ \\
\hline & $95^{\circ} \mathrm{C}$ & 10 & $7.8^{c} \pm 0.0$ & $50.0^{\mathrm{a}} \pm 0.1$ & $16.1^{\mathrm{a}} \pm 0.0$ & $67.2^{\mathrm{b}} \pm 0.0$ & $7.6^{\mathrm{b}} \pm 0.0$ & $11.7^{\mathrm{c}} \pm 0.0$ & $14.1^{\mathrm{b}} \pm 0.0$ \\
\hline & & 15 & $12.2^{\mathrm{d}} \pm 0.0$ & $53.9^{\mathrm{a}} \pm 0.1$ & $16.4^{\mathrm{a}} \pm 0.0$ & $69.0^{\mathrm{b}} \pm 0.0$ & $8.0^{\mathrm{b}} \pm 0.0$ & $16.5^{\mathrm{d}} \pm 0.1$ & $14.1^{\mathrm{b}} \pm 0.0$ \\
\hline & & 20 & $13.0^{\mathrm{d}} \pm 0.0$ & $59.4^{\mathrm{a}} \pm 0.1$ & $17.1^{\mathrm{a}} \pm 0.1$ & $69.7^{\mathrm{b}} \pm 0.1$ & $8.1^{\mathrm{b}} \pm 0.0$ & $18.5^{\mathrm{e}} \pm 0.0$ & $14.6^{\mathrm{b}} \pm 0.0$ \\
\hline
\end{tabular}

Results are means \pm standard error. The values within a column with different superscript letters are significantly $(\mathrm{P}<0.01)$ different. 


\section{Conclusion}

The bioactive compounds of green tea were significantly affected by both extraction temperature and time. It can be concluded that increasing the extraction temperature and time increases the amount of total phenolic and flavonoid contents as well as the antioxidant capacity of tea extracts. The highest total phenolic and flavonoid contents and antioxidant capacity values were obtained from the first shooting period in Sample A which were extracted at $95{ }^{\circ} \mathrm{C}$ for $20 \mathrm{~min}$. The highest amounts of total phenolic and flavonoid contents and antioxidant capacity were observed in the samples obtained from the first shooting period rather than the second and the third shooting periods. The most interesting finding of this study was the decline in catechins when the temperature was increased from $75^{\circ} \mathrm{C}$ to $85{ }^{\circ} \mathrm{C}$. These results also show that 5 minutes are enough to brew Turkish green tea in order to extract almost $80 \%$ of the total phenolics.

\section{Acknowledgements}

The authors would like to thank the Scientific Research Projects Administration Unit of Akdeniz University (Turkey) for financial support (Project number: 2010.02.0121.035), and ÇAYKUR for the green tea samples and support.

\section{References}

Anesini, C., Ferraro, G. E., \& Filip, R. (2008). Total polyphenol content and antioxidant capacity of commercially available tea (Camellia sinensis) in Argentina. Journal of Agricultural and Food Chemistry, 56(19), 9225-9229. PMid:18778031. http://dx.doi.org/10.1021/ jf8022782.

Astill, C., Birch, M., Dacombe, C., Humphrey, P., \& Martin, P. (2001). Factors affecting the caffeine and polyphenol contents of black and green tea infusions. Journal of Agricultural and Food Chemistry, 49(11), 5340-5347. PMid:11714326. http://dx.doi.org/10.1021/jf010759+.

Cabrera, C., Artacho, R., \& Giménez, R. (2006). Beneficial effects of green tea - a review. Journal of the American College of Nutrition, 25(2), 79-99. PMid:16582024. http://dx.doi.org/10.1080/0731572 4.2006.10719518.

Cabrera, C., Giménez, R., \& Carmen-López, M. (2003). Determination of tea components with antioxidant activity. Journal of Agricultural and Food Chemistry, 51(15), 4427-4435. PMid:12848521. http:// dx.doi.org/10.1021/jf0300801.

Chang, Q., Zuo, Z., Chow, M. S. S., \& Ho, W. K. K. (2006). Effect of storage temperature on phenolics stability in hawthorn (Crataegus pinnatifida var. major) fruits and a hawthorn drink. Food Chemistry, 98(3), 426-430. http://dx.doi.org/10.1016/j.foodchem.2005.06.015.

Gadow, A., Joubert, E., \& Hansmam, C. F. (1997). Comparison of the antioxidant activity of rooibos tea (Aspalathus linearis) with green, oolong and black tea. Food Chemistry, 60(1), 73-77. http://dx.doi. org/10.1016/S0308-8146(96)00312-3.

Gürses, O. L., \& Artık, N. (1987). Çay analizyöntemleri (Analysis methods of tea). Ankara: Çay İşletmeleri Genel Müdürlüğü Çaykur Yay.

Hertog, M. G. L., Hollman, P. C. H., \& Putte, B. (1993). Content of potentially anticarcinogenic flavonoids of tea infusions, wines, and fruit juices. Journal of Agricultural and Food Chemistry, 41(8), 1242-1246. http://dx.doi.org/10.1021/jf00032a015.
Higdon, J. V., \& Frei, B. (2003). Tea catechins and polyphenols: health effects, metabolism, and antioxidant functions. Critical Reviews in Food Science and Nutrition, 43(1), 89-143. PMid:12587987. http:// dx.doi.org/10.1080/10408690390826464.

Karori, S. M., Wachira, F. N., Wanyoko, J. K., \& Ngure, R. M. (2007). Antioxidant capacity of different types of tea products. African Journal of Biotechnology, 6(19), 2287-2296. http://dx.doi.org/10.5897/ AJB2007.000-2358.

Khokhar, S., \& Magnusdottir, S. G. (2002). Total phenol, catechin, and caffeine contents of teas commonly consumed in the United Kingdom. Journal of Agricultural and Food Chemistry, 50(3), 565570. PMid:11804530. http://dx.doi.org/10.1021/jf0101531.

Komes, D., Horzic, D., Belscak, A., Ganic, K. K., \& Vulic, I. (2010). Green tea preparation and its influence on the content of bioactive compounds. Food Research International, 43(1), 167-176. http:// dx.doi.org/10.1016/j.foodres.2009.09.022.

Maisuthisakul, P., Suttajit, M., \& Pongsawatmanit, R. (2007). Assessment of phenolic content and free radical-scavenging capacity of some Thai indigenous plants. Food Chemistry, 100(4), 1409-1418. http:// dx.doi.org/10.1016/j.foodchem.2005.11.032.

Ozdemir, F., Gökalp, H. Y., \& Nas, S. (1993). Effects of shooting periods, times within shooting periods and processing systems on the extracts, caffeine and crude fibber contents of black tea. European Food Research and Technology, 197(4), 358-362. PMid:8249478.

Perva-Uzunalić, A., Škerget, M., Knez, Ž., Weinreich, B., Otto, F., \& Grüner, S. (2006). Extraction of active ingredients from green tea (Camellia sinensis): Extraction efficiency of major catechins and caffeine. Food Chemistry, 96(4), 597-605. http://dx.doi.org/10.1016/j. foodchem.2005.03.015.

Pharn-Huy, L., He, H., \& Pham-Huy, C. (2008). Green tea and health: an overview. Journal of Food Agriculture and Environment, 6, 6-13.

Şahin-Nadeem, H., Akdoğan, A., Dinçer, C., Topuz, A., \& Ozdemir, F. (2007). Phenolic composition of different Turkish Green Teas. In Proceedings of the 3rd International Conference on O-CHA (Tea) Culture and Science, Shizuoka, Japan.

Şahin-Nadeem, H., Dinçer, C., Torun, M., Topuz, A., \& Ozdemir, F. (2013). Influence of inlet air temperature and carrier material on the production of instant soluble sage (Salvia fruticosa Miller) by spray drying. Food Science and Technology, 52, 31-38. http://dx.doi. org/10.1016/j.lwt.2013.01.007.

Samaniego-Sanchez, C., Inurreta-Salinas, Y., Quesada-Granados, J. J., Blanca-Herrera, R., Villalón-Mir, M., López-García de la Serrana, H., \& López Martínez, M. C. (2011). The influence of domestic culinary processes on the Trolox equivalent antioxidant capacity of green tea infusions. Journal of Food Composition and Analysis, 24(1), 79-86. http://dx.doi.org/10.1016/j.jfca.2010.06.003.

Singh, H. P., Ravindranat, S. D., \& Singh, C. (1999). Analysis of tea shoots catechins: spectrophotometric quantitation and selective visualization on two-dimensional paper chromatograms using diazotized sulphanilamide. Journal of Agricultural and Food Chemistry, 47(3), 1041-1045. PMid:10552413. http://dx.doi.org/10.1021/jf9807263.

Torun, M., Dincer, C., Topuz, A., Sahin-Nadeem, H., \& Ozdemir, F. (2014). Aqueous extraction kinetics of soluble solids, phenolics and flavonoids from sage (Salvia fruticosa Miller) leaves. Journal of Food Science and Technology, 52(5), 2797-2805. PMid:25892777. http:// dx.doi.org/10.1007/s13197-014-1308-8.

Turkmen, N., Sari, F., \& Velioglu, Y. S. (2006). Effects of extraction solvents on concentration and antioxidant activity of black and black mate tea polyphenols determined by ferrous tartrate and Folin-Ciocalteu methods. Food Chemistry, 99(4), 835-841. http:// dx.doi.org/10.1016/j.foodchem.2005.08.034. 
Vuong, Q., Tan, S. P., Stathopoulos, C. E., \& Roach, P. D. (2012). Improved extraction of green tea components from teabags using the microwave oven. Journal of Food Composition and Analysis, 27(1), 95-101. http://dx.doi.org/10.1016/j.jfca.2012.06.001.

Wang, H., \& Helliwell, K. (2001). Determination of flavanols in green and black tea leaves and green tea infusion by high-performance liquid chromatography. Food Research International, 34(2-3), 223 227. http://dx.doi.org/10.1016/S0963-9969(00)00156-3.

Xi, J., Shen, D., Zhao, S., Lu, B., Li, Y., \& Zhang, R. (2009). Characterization of polyphenols from green tea leaves using a high hydrostatic pressure extraction. International Journal of Pharmaceutics, 382(1-2), 139-143. PMid:19715745. http://dx.doi.org/10.1016/j.ijpharm.2009.08.023.

Yao, L., Jiang, Y., Datta, N., Singanusong, R., Duan, J., Raymont, K., Lisle, A., Xu, Y., \& Liu, X. (2004). HPLC analyses of flavanols and phenolic acids in the fresh young shoots of tea (Camellia sinensis) grown in Australia. Food Chemistry, 84(2), 253-263. http://dx.doi. org/10.1016/S0308-8146(03)00209-7.
Yuan, J. M., Sun, C., \& Butler, L. M. (2011). Tea and cancer prevention: epidemiological studies. Pharmacological Research, 64(2), 123-135. PMid:21419224. http://dx.doi.org/10.1016/j.phrs.2011.03.002.

Zaveri, N. T. (2006). Green tea and its polyphenolic catechins: medicinal uses in cancer and noncancer applications. Life Sciences, 78(18), 2073 2080. PMid:16445946. http://dx.doi.org/10.1016/j.lfs.2005.12.006.

Ziaedini, A., Jafari, A., \& Zakeri, A. (2010). Extraction of antioxidants and caffeine from green tea (Camellia sinensis) leaves: kinetics and modelling. Food Science \& Technology International, 16(6), 505-510. PMid:21339166. http://dx.doi.org/10.1177/1082013210367567.

Zuo, Y., Chen, H., \& Deng, Y. (2002). Simultaneous determination of catechins, caffeine and gallic acids in green, oolong, black and pu - erh teas using HPLC with a photodiode array detector. Talanta, 57(2), 307-331. PMid:18968631. http://dx.doi.org/10.1016/S00399140(02)00030-9. 